\title{
The 4.2 ka event in the Euro-Mediterranean region - A study from the MISTRALS/PALEOMEX program
}

\author{
Bassem Jalali $^{1,2}$ and Marie-Alexandrine Sicre ${ }^{2}$ \\ ${ }^{1}$ GEOGLOB, Université de Sfax, Faculté des Sciences de Sfax, Route de Soukra, Km 4, B.P. \\ 802, 3038 Sfax, Tunisia \\ ${ }^{2}$ Sorbonne Universités (UPMC, Univ Paris 06)-CNRS-IRD-MNHN, LOCEAN Laboratory, 4 \\ place Jussieu, F-75005 Paris, France \\ corresponding-author- (bassemfss@gmail.com)
}

\begin{abstract}
High-resolution records documenting the 4.2 ka event (from 4200 to $3900 \mathrm{cal}$ yr BP) are scarce. Archaeological and paleoenvironmental data from continental archives suggest that this event is coincident with a megadrought in the eastern Mediterranean basin. Here, we present an unprecedented highresolution alkenone-based sea surface temperature (SST) record from the northwestern Mediterranean Sea showing a stepwise cooling of ca. $2^{\circ} \mathrm{C}$ between 4400 and $3800 \mathrm{yr} \mathrm{BP}$, which shares similarities with speleothem records from central Europe and the Mediterranean region. Our data suggest a reorganization of the North Atlantic atmospheric circulation during this event.
\end{abstract}

Keywords: Alkenone, SSTs, 4.2 ka event, Mediterranean, atmospheric circulation.

\section{Introduction}

Holocene rapid climate changes (RCCs) are century-long time intervals of enhanced high-latitudes cooling and tropical dryness (Mayewski et al., 2004; Wanner et al., 2011). One of the most widely documented RCC is the dry and cold period spanning from ca. 4200 to $3900 \mathrm{cal} \mathrm{yr}$ BP, known as the 4.2 ka event (Weiss et al., 2017). This time interval coincides with a megadrought in the eastern Mediterranean basin, which caused the collapse of the Akkadian Empire and the Old Kingdom in Egypt, and further to the far East of the Old Chinese cultures (Weiss and Bradley, 2001; Liu and Feng, 2012; Stanley et al., 2003). The $4.2 \mathrm{ka}$ event is also considered as the boundary between the Middle and Late Holocene (Walker et al., 2012).

In this study we used a recently published high-resolution alkenonebased sea surface temperature (SST) reconstruction from the northwestern Mediterranean Sea (Jalali et al., 2016) and compared it to sev- 
eral speleothem isotope records where the $4.2 \mathrm{ka}$ event is well developed to provide a climatic and environmental regional context to help understanding the response of human societies as documented by archeological excavations.

\section{Materials and Methods}

The gravity core KSGC-31 $\left(43^{\circ} \mathrm{N} ; 3.29^{\circ} \mathrm{E}, 60 \mathrm{~m}\right.$ water depth) was sampled and analyzed for alkenones. The unsaturation index $\mathrm{U}^{\mathrm{k}^{\prime}}{ }_{37}$ and the global calibration published by Conte et al. (2006) were used to calculate SSTs. The age model of the core KSGC-31 between 5500 and 2500 cal yr BP is based on five AMS ${ }^{14} \mathrm{C}$ dates calibrated using the Calib7.1 software and the MARINE 13 calibration data set.

\section{Results and discussion}

Figure 1 shows the SST reconstruction for the Gulf of Lion (GoL; Jalali et al., 2016) together with the air temperature/precipitation records derived from the oxygen isotope of stalagmites from Spannagel (Central Alps), Renella (Italy), Mavri Trypas (southern Greece) and Jeita (Lebanon) caves (see references on Fig. 1). These records are indicative of precipitation changes in central and eastern Mediterranean and are thus used to explore the regional environmental patterns across the basin during the 4400-3800 cal yr BP interval and derive the role of atmospheric modes of variability in the observed changes.

SSTs in the GoL show a several-step cooling of $\sim 2^{\circ} \mathrm{C}$ starting at $4400 \mathrm{yr} \mathrm{BP}$ and culminating at $3800 \mathrm{yr} \mathrm{BP}$ that has never been described at this level of detail. Similar fingerprint is also seen in the air temperature from Central Alps (Fohlmeister et al., 2013; Fig. 1a-b). High-resolution speleothem records from western, central and eastern basins of the Mediterranean (Fig. 1c-d-e) highlight a drastic reduction of rainfall during the 4.2 ka event (Zanchetta et al., 2016; Cheng et al., 2015; Ruan et al., 2016). Cross-analyses of stable oxygen isotopes and archaeological layers from Gueldaman Cave in northern Algeria evidenced that dry conditions between 4400 and $3800 \mathrm{yr}$ BP coincide with the abandonment of the cave (Ruan et al., 2016; Fig. 1c). According to Zanchetta et al. (2016) drier conditions in the Renella cave record in central Italy between 4300 and 3800 yr BP would result of a long dura- 
tion of summer drought (Fig. 1d). Proxy records from eastern Mediterranean (Mavri Trypas and Jeita caves; Cheng et al., 2015; Finné et al., 2017; Fig. 1e, f) further support the occurrence of arid conditions during the $4.2 \mathrm{ka}$ event. The presence of a hiatus in the speleothem record of southern Peloponnese Mavri Trypas Cave even witnesses the absence of stalagmite growth caused by insufficient rainfall. These evidences highlight that precipitations over several parts of the Mediterranean region were extremely low during the 4.2 ka event.

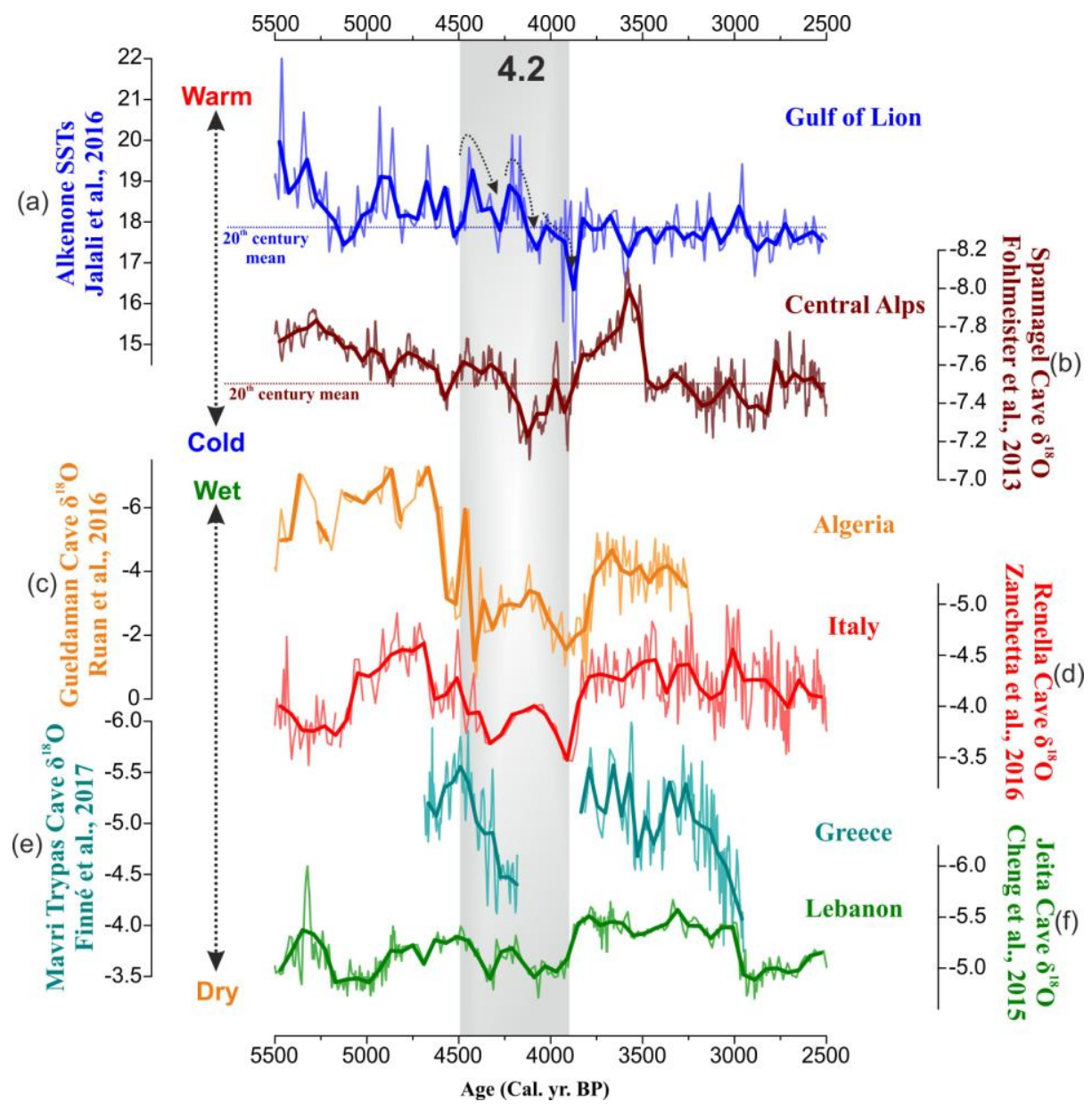

Figure 1: Records of the 4.2 ka event used in this study 
Today, Mediterranean precipitations are controlled by frequency and intensity of Mediterranean cyclones (Genoa Gulf, Gulf of Lion...) originating from the North Atlantic storm tracks (Reale and Lionello, 2013). The Mediterranean cyclogenesis is generally more active when westerlies are weak (weaker zonal flow) allowing cyclones from the North Atlantic to enter the Mediterranean basin and surroundings. However, several paleoreconstructions indicate a strong weakening of the westerly flow (negative North Atlantic Oscillation, NAO) during the 4.2 ka event (O'Brien et al., 1995; Jackson et al., 2005; Olsen et al., 2012). Although Mediterranean winters are expected to be wet under negative NAO, a reverse pattern is expected during North Atlantic atmospheric blocking. In fact, the anticyclonic cell associated with the North Atlantic blocking deflects the westerly wind flow to the North, returning to southern Europe and Mediterranean regions as colder and drier air masses (Hakkinen et al., 2011). Concomitantly coastal regions such as northern England, Ireland and northern Scandinavia benefit from humid conditions (Hughes et al., 2000; Plunkett et al., 2004; Korhola et al., 2002). This weather regime would thus account for the observed dry conditions over the Mediterranean basins during the 4.2 ka event. Similar to the Little Ice Age (LIA), advection of cold northeasterly and northwesterly winds into the Western Europe and NW Mediterranean Sea would be responsible for the cold and dry conditions of the 4.2 ka event (Sicre et al., 2016).

\section{Conclusions}

SSTs in the GoL together with air temperature record from central Alps both show colder conditions during the 4.2 ka event that can be explained by anticyclonic blocking over the North Atlantic as evidenced by the most recent severe climate period know as the LIA. Oxygen isotopes in speleothems indicate that precipitations during this time interval were below normal, reflecting drier continental air flow during this time period as opposed to the maritime westerlies flow that otherwise characterizes the northwestern Europe climate.

Acknowledgments: We thank the MISTRALS/PALEOMEX program and ANR HAMOC (ANR-13-BS06-0003) for financial support. 


\section{References}

Cheng, H., Sinha, A., Verheyden, S., Nader, F. H., Li, X. L., Zhang, P. Z., ... \& Ning, Y. F. The climate variability in northern Levant over the past 20,000 years. Geophysical Research Letters, 42(20), 86418650, (2015).

Conte, M. H., Sicre, M. A., Rühlemann, C., Weber, J. C., Schulte, S., Schulz-Bull, D., \& Blanz, T. (2006). Global temperature calibration of the alkenone unsaturation index (UK' 37) in surface waters and comparison with surface sediments. Geochemistry, Geophysics, Geosystems, 7(2).

Finné, M., Holmgren, K., Shen, C. C., Hu, H. M., Boyd, M., \& Stocker, S.: Late Bronze Age climate change and the destruction of the Mycenaean Palace of Nestor at Pylos. PloS one, 12(12), e0189447, (2017).

Fohlmeister, J., Vollweiler, N., Spötl, C., \& Mangini, A.: COMNISPA II: Update of a mid-European isotope climate record, 11 ka to present. The Holocene, 23(5), 749-754, (2013).

Häkkinen, S., Rhines, P. B., \& Worthen, D. L.: Atmospheric blocking and Atlantic multidecadal ocean variability. Science, 334(6056), 655-659, (2011)

Hughes, P. D., Mauquoy, D., Barber, K. E., \& Langdon, P. G.: Mire-development pathways and palaeoclimatic records from a full Holocene peat archive at Walton Moss, Cumbria, England. The Holocene, 10(4), 465-479, (2000).

Jackson, M. G., Oskarsson, N., Trønnes, R. G., McManus, J. F., Oppo, D. W., Grönvold, K., ... \& Sachs, J. P.: Holocene loess deposition in Iceland: Evidence for millennial-scale atmosphere-ocean coupling in the North Atlantic. Geology, 33(6), 509-512, (2005).

Jalali B, Sicre MA, Bassetti MA et al.: Holocene climate variability in the North-Western Mediterranean Sea (Gulf of Lions). Climate of the past 12: 91-101, (2016).

Korhola, A., Vasko, K., Toivonen, H. T., \& Olander, H.: Holocene temperature changes in northern Fennoscandia reconstructed from chironomids using Bayesian modelling. Quaternary Science Reviews, 21(16-17), 1841-1860, (2002).

Liu, F., \& Feng, Z. (2012). A dramatic climatic transition at 4000 cal. yr BP and its cultural responses in Chinese cultural domains. The Holocene, 22(10), 1181-1197.

Mayewski, P. A., Rohling, E. E., Stager, J. C., Karlén, W., Maasch, K. A., Meeker, L. D., ... \& LeeThorp, J.: Holocene climate variability. Quaternary research, 62(3), 243-255, (2004).

O'brien, S. R., Mayewski, P. A., Meeker, L. D., Meese, D., Twickler, M. S., \& Whitlow, S. I.: Complexity of Holocene climate as reconstructed from a Greenland ice core. Science, 270(5244), 1962 1964, (1995)

Olsen, J., Anderson, N. J., \& Knudsen, M. F.: Variability of the North Atlantic Oscillation over the past 5,200 years. Nature Geoscience, 5(11), 808, (2012).

Plunkett, G. M., Whitehouse, N. J., Hall, V. A., Brown, D. M., \& Baillie, M. G. L.: A precisely-dated lake-level rise marked by diatomite formation in northeastern Ireland. Journal of Quaternary Science, 19(1), 3-7, (2004).

Reale, M., \& Lionello, P.: Synoptic climatology of winter intense precipitation events along the Mediterranean coasts. Natural Hazards and Earth System Sciences, 13(7), 1707-1722, (2013).

Ruan, J., Kherbouche, F., Genty, D., Blamart, D., Cheng, H., Dewilde, F., ... \& Michelot, J. L.: Evidence of a prolonged drought ca. $4200 \mathrm{yr}$ BP correlated with prehistoric settlement abandonment from the Gueldaman GLD1 cave, Northern Algeria. Climate of the Past, 12(1), 1-14, (2016).

Sicre, M. A., Jalali, B., Martrat, B., Schmidt, S., Bassetti, M. A., \& Kallel, N.: Sea surface temperature variability in the North Western Mediterranean Sea (Gulf of Lion) during the Common Era. Earth and Planetary Science Letters, 456, 124-133, (2016).

Stanley J, Krom M, Cliff R et al.: Nile flow failure at the end of the Old Kingdom, Egypt: Strontium isotopic and petrologic evidence. Geoarchaeology 18: 395-402, (2003). 
Walker, M. J., Berkelhammer, M., Björck, S., Cwynar, L. C., Fisher, D. A., Long, A. J., ... \& Weiss, H. (2012). Formal subdivision of the Holocene Series/Epoch: a discussion paper by a working group of INTIMATE (Integration of ice-core, marine and terrestrial records) and the subcommission on Quaternary Stratigraphy (International Commission on Stratigraphy). Journal of Quaternary Science, 27(7), 649-659.

Wanner, H., Mercolli, L., Grosjean, M., and Ritz, S. P.: Holocene climate variability and change; a data-based review. J. Geol. Soc. London, 172, 254-263, doi:10.1144/jgs2013-101, (2014).

Weiss, H., \& Bradley, R. S.: What drives societal collapse?. Science, 291(5504), 609-610, (2001).

Weiss, H. (2016). global megadrought, societal collapse and resilience at 4.2-3.9 ka BP across the mediterranean and west asia. PAGES, 24, 62-63.

Zanchetta, G., Regattieri, E., Isola, I., Drysdale, R. N., Bini, M., Baneschi, I., \& Hellstrom, J. C.: The so-called " 4.2 event" in the central Mediterranean and its climatic teleconnections. Alp Mediterr Quat, 29, 5-17, (2016). 